\title{
Entre braços e pernas: prostitutas estrangeiras na literatura brasileira do século $X X$
}

Berta Waldman

O intuito deste trabalho é o de alinhavar, através da leitura de textos literários, uma reflexão sobre um aspecto particular da imigração no Brasil - a prostituição de mulheres estrangeiras. Sabe-se, e a historiografia que trata dos processos imigratórios datados do final do século é vasta, que o surto desenvolvimentista da cidade de São Paulo atinge dimensões impressionantes do ponto de vista industrial, comercial e demográfico, que acabam por transformá-la no pólo mais importante do Brasil, e num de seus mais influentes centros de decisão política. E isso se deveu em grande parte aos imigrantes que aportaram no país para substituir o braço escravo, que deixa de ser explorado com a abolição da escravatura, em 1888, respondendo à demanda de ampliação das áreas cafeeiras que exigiam crescentes aportes de mão-de-obra. Um facção da elite econômica - os fazendeiros do café -, detentora, então, do controle político do estado, optou pela imigração para resolver o seu problema de auferir lucros mediante o trabalho barato, incentivando e subvencionando a vinda ao país de grande contingentes de trabalhadores europeus. ${ }^{1}$

Abdelmalek Sayad, em seu livro $A$ Imigração, ${ }^{2}$ chama a atenção para uma questão que pode parecer elementar, mas é, a meu ver, fundamental: a de que a imigração tem de ser vista como "um fato social completo", que leve em conta a existência do "emigrante", aquele que saiu de sua comunidade, sociedade, país, e a do "imigrante", aquele que chegou a uma terra estranha. O paradoxal, mostra Sayad, é que ambos são a mesma e única pessoa. O imigrante "nasce" no momento em que assim é designado pela sociedade que o acolhe. Mas desconhecer o que antecede 
esse momento é uma das versões do etnocentrismo, que mutila uma das partes de seu objeto, a parte relativa à emigração.

Embora o princípio colocado possa parecer banal, é interessante observar como a figuração desse objeto se organiza de forma fragmentária, enfatizando-se ora o imigrante, com o apagamento do emigrante, ora o inverso, dependendo dos interesses postos em ação.

Em termos da produtividade do trabalho no campo, na cidade, nas indústrias nascentes, interessava que o imigrante fosse uma máquina, sem nenhum outro aporte que não o do trabalho efetivo. Vejam-se, a propósito, os dispositivos repressivos criados pelo Estado ${ }^{3}$ para obstruir a circulação de idéias alienígenas, marcas de línguas estrangeiras, publicações de periódicos de comunidades estrangeiras etc., podando, assim, o lastro de fora que deveria ser apagado, para se erigir a identificação do estrangeiro com o mesmo, quebrando-se, à força, qualquer jogo de alteridade.

Em contrapartida, a literatura brasileira do século XX é amplamente protagonizada por prostitutas estrangeiras aglutinadoras do desejo masculino, ${ }^{4}$ justamente por ocuparem o lugar esfumado da "outra", da que veio de fora. É sobre a prostituição feminina estrangeira que vou me deter daqui para frente, para observar como há duas medidas para um mesmo modelo imigratório.

Macunaíma, personagem do romance homônimo de Mário de Andrade, ${ }^{5}$ um dos marcos do modernismo brasileiro, envia, em linguagem empolada e paródica, uma carta às Icamiabas ${ }^{6}$ suas súditas, onde relata como ele, nascido "no fundo do mato virgem" vê a cidade de São Paulo. Entre as notícias, as prostitutas estrageiras ocupam lugar de destaque:

Sabereis mais que as donas de cá não se derribam à paulada, nem brincam por brincar, gratuitamente, senão que a chuvas do vil metal, repuxos brasonados de champagne, e uns monstros comestiveis, a que, vulgarmente dão o nome de lagostas. [...] 
Falam numerosas e mui rápidas línguas; viajadas e educadíssimas, sempre todas obedientes por igual, embora ricamente díspares entre si, quais loiras, quais morenas, quais fôsse maigres, quais rotundas; e de tal sorte abundantes no número e diversidade, que muito nos preocupa a razão, o serem todas e tantas, originais de um pais somente. Acresce ainda que a todas se lhes dão o excitante, embora injusto, epiteto de "francesas". A nossa desconfiança é que essas damas não se originaram todas na Polônia, porém que faltam à verdade, e são iberas, itálicas, germânicas, turcas, argentinas, peruanas, e de todas as outras partes férteis de um e outro hemisfério.

O olho clínico do personagem registra não só as prostitutas, mas a farsa de todas se apresentarem como francesas ou polacas, as mais bem cotadas na época. Além disso, ele menciona o champanhe, a lagosta, enfim, a introdução de hábitos alimentares e de consumo de bebidas associados à sociabilidade, a lugares de encontro, que, de fato, têm a ver com sua atuação nas grandes cidades brasileiras do início do século XX.

Já no século XIX, as "mulheres públicas" do Rio de Janeiro foram recrutadas não só entre as brasileiras, como também entre as estrangeiras, principalmente africanas libertas e européias. Machado de Assis trata da presença de prostitutas européias na cidade já nas primeiras décadas do século XIX, ao relatar o episódio do jovem Brás Cubas, ${ }^{7}$ que, no início dos anos 1820, fora mandado por seus pais à Europa, para estudar direito na Universidade de Coimbra, porque se apaixonara por Marcela, espanhola encantadora e devassa. A paixão do jovem pela cortesã levou-o a cometer desatinos, e, por isso, acaba sendo embarcado à força para Portugal. No romance O Bom Crioulo, de Adolfo Caminha, ${ }^{8}$ há a prostituta portuguesa famosa por suas pernas, Dona Carolina, que mais tarde largaria o meretrício para viver do aluguel de quartos de sua casa na Rua da Misericórdia. Dando um salto de algumas décadas, em Amar, verbo intransitivo, ${ }^{9}$ Mário de Andrade apresentará não uma prostituta, mas uma preceptora alemã incumbida de instruir o jovem e iniciá-lo na sexualidade, incluindo o sexo higienizado no rol dos atributos de um processo 
de formação. Na outra ponta desse modelo de prostituição estrangeira, e no período que antecede o grande fluxo imigratório da virada do século, está a negra escrava, cujo corpo é devassado pelo colonizador português, marcando, com seu abuso, o símbolo da relação que iconiza a dominação, ou a forma de constituição da colônia. Aí, o estupro, a violência que se infiltra pela intimidade, traduz um conceito de economia patriarcal que funde o público e o privado e organiza a regra básica da sociabilidade brasileira. A invasão perversa do outro denuncia o negro como nãoigual, e a permissividade do senhor não se confunde, como pode parecer, com falta de preconceito, mas se delineia como falta de distância, como invasão legítima do outro perpetrada pelo proprietário. ${ }^{10}$

\section{Menos sexo/mais-valia}

Como Velásquez em "Las Meninas", Hilário Tácito pinta, no romance Madame Pommery ${ }^{11}$ (publicado originalmente em 1920), o quadro histórico da cidade de São Paulo do início do século e deixa um espaço na tela para pintar-se a si mesmo com os pincéis na mão.

Entre o propósito declarado de narrar a vida da prostituta "francesa" - Mme. Pommery - e os descaminhos que o conduzem à construção de uma identidade autoral opaca, pois já na origem ela se ancora num pseudônimo de José Maria de Toledo Malta (1885-1951), o romance conduz-se por um fio que vai e vem: parte do que conta ao objeto contado, vai do olho que se calibra permanentemente para funcionar como o de um narrador-cronista e faz uma parada na realidade segmentada - a representação da cidade de São Paulo e as transformações por que passa no início do século, a partir da instalação de um bordel de alta prostituição - para continuar se desdobrando do começo ao fim.

Como se vê, a figuração desse narrador-cronista não é simples. Sua proposta inicial é a de fazer um relato objetivo, colocando-se como testemunha ocular dos acontecimentos. Entretanto, esse ponto de vista 
deixa-se atravessar por falas alheias, carregando o texto de citações que mesclam o português com línguas estrangeiras, o registro erudito com o popular, a linguagem escrita com formas orais, cruzando perspectivas já cindidas a partir da própria matriz do relato que oscila entre ficção e história, pondo em xeque uma suposta unidade do sujeito que narra.

O resultado é um estilo precioso e ambíguo, apoiado no tom satírico e na ironia que dimensionam seus objetos de forma contraditória; assim, o grande é também pequeno, o que se constrói também se corrói. Esse jogo de contrários, aliás, está presente na própria construção do pseudônimo com que o autor assina seu único romance, e que, segundo ele, significa "rir calado". ${ }^{12}$ Se Hilário tem a ver com sentidos relativos à graça e ao riso, Tácito traz uma referência séria, erudita, evocando a figura do famoso historiador latino da antigüidade, Publius Cornelius Tacitus. É no curso errático do sério ao deboche que se constroem as digressões em cujas malhas se prendem "autor", personagem, narrativa. ${ }^{13}$

Também o nome Pommery evoca duas conhecidas referências: Madame Bovary, protagonista do romance de Gustave Flaubert de mesmo nome, publicado em 1857, e Madame Pompadour, dama da corte de Luís XV, tornada célebre como a favorita do rei. Pommery é, ainda, a marca de um champanhe francês, que a protagonista orgulha-se de ter introduzido na noite paulistana. Note-se que na combinação Bovary/Pompadour justapõem-se duas fontes: uma literária, outra histórica, o que reforça a intenção do autor, aliás cumprida, de construir uma narrativa entre a ficção romanesca e a crônica de costumes. Retomando certo tom crítico do romance realista do século XIX que tinha por alvo o ataque à falsa moralidade burguesa e oferecendo, ao mesmo tempo, uma crônica da prostituição paulistana do início do século XX, o autor traz também para o texto os ecos da tradição francesa da sátira de costumes, permanecendo num espaço intervalar, que, ao final, ultrapassa esses limites, instalando o texto num lugar particular.

$\mathrm{O}$ romance aponta para um momento da vida paulistana em que a privatização do sexo, consubstanciada pelo casamento monogâmico e 
encerrada no quarto de casal, é valorizada pela Igreja, pela medicina higienista e pelo Estado. Na contramão, a prostituição instaurará formas coletivas e diferenciadas de circulação do desejo, acompanhando de perto a circulação do dinheiro. ${ }^{14}$

Fica claro, no romance, que o dinheiro é o elemento dimensionador de um novo sentido para o sexo, porque ele tem o poder simbólico imediato de estabelecer os limites de como e por onde deve circular o desejo. Significante sem referente - um mesmo valor compra indistintamente automóveis, alimentos, medicamentos, arte, sexo -, o dinheiro abre espaço para a encenação de pulsões que não se realizam na relação conjugal normatizada pelo casamento. Também a prostituta é um significante que não se fixa num referente; de todos e de ninguém, ela é sempre uma projeção do desejo masculino.

A pergunta que subjaz a essa reflexão é por que, num contexto histórico que exigia o apagamento da cultura de origem para se obter um maior rendimento no trabalho e a adaptação imediata do estrangeiro à nova terra, a proveniência estrangeira da prostituta é supervalorizada?

Talvez essa necessidade - para além da representação da Europa como continente padrão do desenvolvimento que incluía cultura, produção de bens materiais, etiqueta, moda, formas de sociabilidade, a serem almejadas e, se possível, imitadas - esteja relacionada à natureza obscura do feminino. Embora a indagação sobre o feminino encontre uma resposta fácil em sua capacidade anatômica de procriar, a questão não se resolve por essa via, uma vez que as mulheres imigrantes que consituíam família ficavam fora dessa esfera, perfilando-se, ao lado de seus maridos, como braço de trabalho, e não como "pernas vagabundas"15 conforme a metonímia utilizada no texto para designar as prostitutas. É difícil dizer de que é feita essa natureza, por isso mesmo é possível afirmar sua obscuridade. E, porque obscura, ela imanta o sentido de desconhecido, estrangeiro, promovendo uma transposição metafórica em que feminino e estrangeiro se somam. Assim, o apelo que a prostituta estrangeira exerce estaria vinculado não apenas à importação de formas de práticas eróticas 
desconhecidas, mas, principalmente, ao fato de ela portar um sentido inalcançável, que sempre escapa. Recoberta de múltiplas imagens, repositório de atributos como independência, licenciosidade e poder, a prostituta é uma figura que brota no solo da modernidade associada à liberalização dos costumes, à desconexão com os vínculos sociais tradicionais e à multiplicidade de novas práticas sexuais. Enquanto a urbanização e o crescimento socioeconômico da cidade embaralhavam as tradicionais demarcações entre atividades masculinas e femininas com a entrada em cena das mulheres nas fábricas, no comércio, escritórios, escolas, ameaçando subverter os códigos cristalizados de sociabilidade e de participação na vida social, a figura da prostituta emerge como um poderoso fantasma no imaginário social.

A linha da vida de Madame Pommery, nascida Ida Pomerikowsky, é marcada pela itinerância. Filha de pai judeu-polonês charlatão e de mãe espanhola ex-noviça e devassa, nasce Ida, não se sabe bem onde, herdando "disposições para a disciplina (resíduo atávico de clausuras antepassadas) e taras patológicas de insofrível concupiscência". ${ }^{16}$ As marcas paternas, forjadas de um estereótipo de judeu, serão mais determinantes em sua formação:

\section{Transmitiu-lhe o nariz adunco, estigma da raça, e, concomitantemente, o gosto das finançs, a cupidez e o faro mercantil. ${ }^{17}$}

Aos três anos foge-lhe a mãe, e Ida passa a ser educada por uma preceptora cigana, também amante de seu pai. A formação de "guapa" e "salerosa" que incluía dançar, sapatear, ler a sorte, lidar com o ursos (o pai era domador de circo) etc. tinha por horizonte habilitá-la para auferir lucros ao pai que tinha em mente vender sua virgindade. Escolhido o pretenso estuprador e estabelecido o valor da operação, Ida passa uma rasteira no pai, fugindo com o dinheiro e a cigana, estreando na prostituição itinerante por conta própria, prática que a conduzirá a diferentes nações e cidades européias. Aos 34 anos, gorducha e outoniça, mas ainda 
em plena posse de seus poderes de sedução, a protagonista resolve acompanhar um marujo normando ao Novo Mundo. Resolve "fazer a América", chegando por acaso, ou por destino, ao porto de Santos, São Paulo. Vinha num cargueiro que parou para se abastecer de café e bananas para a República Argentina e descarregou vinho, sardinhas, bacalhau, 2.000 volumes de Zola, 40 caixas de champanhe e Mme. Pommery que, já no primeiro bar, topou com a ex-preceptora, a cigana Zoraida, com pose de dama respeitável, que fez que não a viu, enquanto ostentava com ar de dona o seu consorte. Ainda nesse bar, a protagonista toma sua primeira lição de Brasil:

\section{Aqui, quando um freguês não é doutor, é coronel. ${ }^{18}$}

A descoberta de um clássico coronel serve como porta de entrada para o seu entendimento do país. Se os coronéis são os ricos e poderosos do lugar, explorá-los torna-se sua meta imediata.

Em São Paulo, a protagonista exerce suas artes para sobreviver, ao mesmo tempo em que toma a si a incumbência de "civilizar" a vida airada da cidade, mediante a abertura de seu cabaré modelo, não sem antes fazer um levantamento do comércio libertino local que aponta para "a insipidez de nossos hábitos noturnos", "o meretrício indigente e reles", "o elemento nacional anarquizado e incompetente". Como vocifera o coronel Pinto Gouveia, reforçando a necessidade imediata de levar a cabo a inauguração do bordel:

Proclamam os nossos estadistas que não basta atrair para aqui os braços estrangeiros. Que é preciso fixá-los; prever tudo, intentar tudo, para os ter em nossa terra, fixos e permanentes. Pois a mesmissima coisa, sem falta nenhuma, é o que se há de dizer das pernas estrangeiras para as termos à mão: - fixá-las.19 
Se os freqüentadores da noite estão interessados em fixar "as pernas", e os estadistas e a elite econômica, "os braços", a voz a contrapelo do narrador arremata um outro ponto de vista quando afirma:

A cidade de São Paulo é uma capital cosmopolita, onde ao antigo elemento nacional, ainda em maioria, se vieram misturar, numa indigesta confusão de raças e de civilizacõoes, outras gentes escumadas de todas as terras do mundo, desde a Grécia até o Japão.

Dai a grande e natural instabilidade com que aqui se apresentam todos os usos e costumes, sempre inclinados a revestir formas, ora extravagantes, ora ridiculas, no seu desenvolvimento excessivamente rápido, de contínuo perturbado por influências forasteiras. ${ }^{20}$

São oscilações como essa, feitas a partir da conjunção de vozes, do deslizamento do ponto de vista e do tom, que forjam as medidas híbridas com que o texto vai se alinhavando.

Mas para fundar seu empreendimento progressista, a protagonista necessita de dinheiro. Falta-lhe capital, que ela consegue desse mesmo velho coronel solteirão em troca do privilégio de torná-lo seu amante oficial. Estabelecida a firma, a etapa seguinte é a da divulgação do produto e dos serviços da empresa. Descarta, então, o coronel e seduz um médico, o dr. Mangancha, diretor da "Companhia Paulista de Teatros e Passatempos", que explorava o Teatro Cassino. O médico facilita-lhe a contratação de colaboradoras de qualidade, mulheres estrangeiras resgatadas do elenco do Cassino, e arranja-lhe, nesse mesmo teatro, frisas onde todas as noites ela luzia sua mercadoria.

Conseguida a clientela, os próximos obstáculos ao sucesso do empreendimento são de ordem burocrática, causados pelas regulamentações municipais. Para esses serviços Mme. Pommery troca o dr. Mangancha por Romeu de Camarinhas, jovem bacharel da Intendência. Nessas alturas ela já é rica o bastante para rivalizar com os coronéis. 
As alianças que faz e desfaz, segundo suas conveniências, indicam o acerto de sua compreensão do funcionamento da sociedade de então. ${ }^{21}$ Ela afinal obtém os favores e os serviços de homens que representam algumas das principais instituições que alicerçavam a estrutura da República Velha: o coronel, o alto burocrata e o bacharel.

Graças ao uso eficaz desses favores, a protagonista consegue imprimir à prostituição uma perspectiva empresarial, transformando seu bordel-modelo numa máquina capitalista bem montada.

O romance enfatiza a importância do bordel enquanto "escola de civilidade", pois aí se aprendiam regras modernas de interação social no submundo, desfilavam-se as modas francesas e degustavam-se bebidas importadas, ao som de ritmos excitantes.

Cursar o Paradis Retrouvé ficon sendo, no conceito geral da gente fina,

um título de merecimento e remate indispensável de toda educação aprimorada..$^{22}$

Local de encontro de homens e mulheres de diferentes extratos sociais, de jovens e velhos, por lá circulavam literatos, jornalistas, políticos, fazendeiros, comerciantes, tornando-se passagem obrigatória para aqueles que queriam aprender os hábitos da vida noturna. Também as moças da sociedade absorviam indiretamente novos hábitos, comportamentos, além da moda parisiense, na medida em que imitavam as cocotes, verdadeiros "figurinos vivos e últimos modelos de elegância". ${ }^{23}$

Esse lado da sociabilidade e do aprendizado, no entanto, só se efetiva porque o bordel se impõe como o lugar simbólico privilegiado para propiciar fantasias de escape do isolamento da vida conjugal. ${ }^{24} \mathrm{O}$ papel de caftina que Mme. Pommery exerce estabelece uma relação de exterioridade com o desejo. Como empresária, ela envolve-se indiretamente com o freguês, promove encontros, articula contatos, calcula preços e margens de lucro, engendra inovações a serem implementadas para alcançar maior êxito do investimento. O luxo, o ambiente voluptuoso feito de tapetes, espelhos, iluminação, gravuras eróticas, bebidas afrodisí- 
acas, funcionam como um cenário de teatro, onde as mulheres, sempre fora de si, atravessadas pelo desejo do outro, encenam papéis de um roteiro fixo, que aponta para a promessa de um labirinto de sensações. Mas esse é um lado. Há, no romance, as manobras capitalistas da protagonista, que deixam bem claro, desde o início, o que ela ambiciona. $\mathrm{E}$, se ela encena junto ao homem os seus papéis como prostituta ou como caftina, corresponder ao desejo do outro é o meio utilizado, como um trampolim, para alcançar seus objetivos. Primeiro, o dinheiro. Bemsucedida em sua empresa, ela abandonará o negócio próspero, porque pretende agora partilhar dos "bons costumes", para tornar-se uma mulher "respeitável". Ela quer se casar e aumentar, quiçá, o patrimônio. Para isso, venderá o bordel e sairá de férias para a Europa, não antes de esboçar a lista dos candidatos para o lugar de marido. Não mais coronéis, burocratas ou bacharéis, é a vez dos comerciantes, e ela anota o nome de três novos-ricos, dois deles de origem estrangeira, o terceiro, talvez. Enfim, Mme. Pommery sabe para onde sopra o vento. Figura determinada, arma-se do cabedal de astúcias aprendido em casa e nas andanças pela Europa, e, uma vez no Brasil, rapidamente aprende a mecânica de funcionamento da nova sociedade, transitando, com habilidade, por diferentes sistemas de valores e práticas.

Assim, o trânsito no espaço que caracteriza a personagem desde o início é também trânsito entre posições e papéis mobilizadores de seus interesses. Desenraizada, destituída de escrúpulos e de qualquer sombra de lastro ético, ela se mostra como uma caricatura vazia posta em circulação, como o desejo que se quer moeda numa sociedade capitalista. $\mathrm{Na}$ outra ponta, o autor, porque faz uso da caricatura, abre mão dos meiostons e da espessura e abdica de qualquer pretensão idealizante em relação à sua criatura, relevando sua contribuição para a modernização dos prazeres, para a formação de novos hábitos e práticas na noite paulistana, ao mesmo tempo em que acentua o traço kitsch dessa mesma modernização em processo, apontando para o mau gosto de seu empreendimento que 
guarda vestígios do provincianismo. Veja-se, como exemplo, a maneira como descreve o bordel:

Poucos ornatos [havia na entrada]: um centro de metal branco na mesa grande, com flores murchas, e meia dúzia de estampas nas paredes, gravuras de nus cortadas da "Tllustration". [...] As mesas eram de pinho encerado; mas as toalhas alvas cobriam tudo. As cadeiras, de palbinha; austriacas, ordinárias. Ordinário, aliás, era ali tudo que se via à vista de olhos sãos; mas a luz elétrica era excessiva, o champanha obrigado, próxima a tentação da carne. E, como a luz ofusca, o vinho embriaga e a luxúria transtorna, as toalhas alvas, os copos, os quadros, as flores e a própria burra, tudo brilhava com um brilho sedutor. ${ }^{25}$

Quer dizer, esse cenário se monta em duas faces, à maneira de um recorte cubista: se visto pelo biógrafo, aquele que almeja, na qualidade de cronista, "a verdade", põe a nu seu costado decadente e de falso luxo; mas, se visto pelos fregueses embriagados e expectantes de uma noitada de luxúria, mostra-se recoberto de brilho sedutor. Esse exemplo é sintomático do modo como o autor trabalha com diferentes medidas a sua matéria, ao mesmo tempo em que a mimetiza na forma, através de suas várias vozes e desvios narrativos que forjam a labilidade de um lugar de enunciação que se sustenta na corda bamba entre o sério e o riso. Pode-se aproximar, por esse ângulo, as memórias de Mme. Pommery d'As Memórias de um Sargento de Milícias, de Manuel Antônio de Almeida, e d'As Memórias Póstumas de Brás Cubas, de Machado de Assis, e, ainda, situar o romance como o arauto de um certo tom debochado que, com Oswald de Andrade, virá à luz nos anos 20, e fará escola durante o modernismo. 


\section{2. $O$ sexo da sereia}

(O Ciclo das Águas), romance de Moacyr Scliar publicado em $1977,{ }^{26}$ tem como pano de fundo a experiência da imigração judaica no Brasil, circunscrevendo um episódio histórico preciso: o tráfico de prostitutas ocorrido na década de 30 , em que se situa a ação.

A protagonista é Esther, filha de um mobel, ${ }^{27}$ nascida num pequeno povoado da Polônia, onde apascentava cabras; sua família era uma típica família judaica da Europa Oriental, que vivia na pobreza e no respeito às leis da tradição. Casa-se com Mêndele, jovem da mesma aldeia, que, depois de uma estada de anos em Buenos Aires, volta para seu lugar de origem e usa o casamento como artifício para trazer a jovem esposa aos bordéis da América. Como Mme. Pommery, Esther sente-se atraída pela América, mas ela se dispõe a seguir o marido movida por amor, e acaba sendo partícipe de um plano que ignora. Partem, o marido não a toca, reservando-a para ser desvirginada por outro homem em Paris, onde fazem uma parada planejada, sendo, a partir daí, definitivamente iniciada nas artes profissionais do sexo. Morre-lhe o marido a caminho de Buenos Aires, mas a moça já é esperada pela organização que a conduz ao bordel. De Buenos Aires, centro da máfia judaica do continente, vai a Porto Alegre, onde fará sua vida. Terá um filho, Marcos, que será criado por uma ama, dentro do ritual judaico. Esther terá seu bordel que conduzirá com mãos de ferro, alcançará sucesso e dinheiro, mas sofrerá decadência e acabará seus dias num asilo, acompanhada de seu último amante, o ladrão Gatinho, e de seu filho, já homem adulto, professor de História Natural, casado com uma não-judia e pai de dois filhos.

A linearidade parafrástica que acabo de expor não equivale à maneira como o romance é construído. Recortado por uma pluralidade de vozes que soam em terceira (Esther) e primeira pessoa (Marcos), ${ }^{28}$ os capítulos unem-se por contigüidade, rastreando uma palavra ou frase do final de uma parte para o início de outra, aglutinando no novo contexto outro sentido, enquanto a ação se direciona para outro lugar, apoiados 
esses deslocamentos em distâncias narrativas e pontos de vista diversos, o que imprime à narração entrecortada uma trajetória de arabescos, resultando a construção num intrincado painel feito de implicações formais, só apreendido quando se segue cada um dos rastros. Não é aleatório o uso dos parênteses presentes no título do romance e dos capítulos, nem é aleatório o fato que seu fim seja também seu recomeço, pois é pelo título que o romance termina, iconizando na forma o motoperpétuo representado tematicamente pelo ciclo das águas, onde a vida se devora, se transforma e se refaz. Mas o ciclo das águas é também o fluxo da linguagem, lugar onde se vive e se morre, onde ficção e mito se alimentam de detritos e, autofagicamente, de si próprios. Os parênteses marcam, talvez, essa dobra metalingüística que vinca a narrativa em espelho, delimitando a presença de outro registro que corre paralelo. Veja-se, à guisa de exemplo, essa passagem da escrita de (Marcos), que perde os parênteses quando mergulha nas águas do que é contado:

Sobre riachos falo aos alunos, mas sobre a Pequena Sereia, não: as águas que ela habita são outras. À noite, após a aula, volto para casa e tiro da gaveta a pasta azul. Folheio o que escrevi; sob meus olhos fatigados a Pequena Sereia adquire vida; descrita embora em má prosa, ela evolui em águas límpidas. Graciosa criatura? ${ }^{29}$

A sereia acompanhará o trajeto de Esther, caracterizado, como o de Mme. Pommery, pelo trânsito. Habitando duas medidas simultâneas - o alto e o baixo, o presente e o passado, o mito e seu equivalente "real" -, Esther faz o trajeto que a conduz do espaço aberto, o alto de amenas colinas da Polônia, para o aprisionamento do asilo em Porto Alegre; mas, sem abdicar do que viveu, carrega consigo a família perdida, o lugar onde nasceu, a tradição judaica a que pertence, pautando sua vida por ela, fazendo seu filho cumprir os rituais de passagem (circuncisão, bar-mitzvâ), ${ }^{30}$ apesar de a comunidade judaica a repudiar nos espaços públicos, embora a procurasse na intimidade do bordel para iniciar jovens 
judeus no sexo. É por um deles, Rafael, o pai de seu filho, que ela se apaixonará.

A sereia marca a vida de Esther a partir de seus doze anos, portanto, a partir de sua iniciação na maioridade, seu bat-mitzváa, ${ }^{31}$ quando o capitão polonês a senta sedutoramente em seus joelhos e conta-lhe a história da Pequena Sereia. O reencontro com a Sereia se dará na Casa dos Prazeres, em Paris, onde foi desvirginada, e de onde carrega consigo um abajur com a imagem de uma sereia que a acompanhará até o fim de seus dias. Quando passa a proprietária de um bordel, Esther dá-lhe o nome de $A$ Pequena Sereia.

O primeiro encontro faz o corte de Esther com a cultura religiosa judaica tecida por rituais, comportamentos e histórias lidas na Bíblia, introduzindo-a, pela narrativa, no mundo laico, ao mesmo tempo em que se dá a descoberta da sexualidade estimulada por um homem de fora de sua comunidade. O segundo assinala a jovem prostituída e, por isso, sua exclusão da estrutura familiar, da comunidade judaica e de seu país de origem. O terceiro releva o sucesso de sua empreitada, afinal, ela consegue "fazer a América", seguido, porém, de decadência física e fracasso econômico, representados pela sereia atada na antena de seu jipe vermelho e velho, como o porta-estandarte de uma vida feita de altos e baixos, sucessos e fracassos.

A sereia, metade mulher, metade peixe, é um dos mitos que habitam o mar. Seu papel é o de seduzir os navegadores pela beleza do rosto e pela melodia do canto, atraindo-os para a morte no oceano. Ulisses fezse atar ao mastro de seu navio para sobreviver e ao mesmo tempo experimentar a beleza do canto, ao contrário dos remadores que o acompanhavam, que, tapando os ouvidos com cera, pagaram um alto preço por sua sobrevivência: a exclusão do contacto com o belo de suas vidas.

Imagem híbrida, a sereia apresenta na completude de sua forma a incompletude das partes de que é feita. $\mathrm{O}$ acabado da figura tira qualquer perspectiva de complementação das metades, o que cerca essa figura de um halo de ambigüidade, mantida pelo fato de ser feminina, mas não ter 
sexo, vivendo desemparelhada de machos de sua espécie, que não existem. O romance, entretanto, forja seu meio de reprodução:

A reprodução é assexuada, e se produz a intervalos de anos. Passa então por uma curiosa transformação! Os movimentos se entorpecem, o apetite diminui. Deitada no fundo do riacho, vê os braços se cobrirem de minúsculas escamas. Horrorizada, talvez, mas de qualquer modo impotente para deter o processo, observa as escamas se espalharem: ventre, seios, rosto aos poucos vão sumindo. Por fim, restam duas caudas unidas. Agitam-se para cima e para baixo como loucas, chegam a saltar fora d'água; até que começam a se separar - e duas pequenas sereias se revelam. ${ }^{32}$

Essa figura anfíbia seduz, mas nega a posse amorosa, movendo as pulsões obscuras e primitivas do homem, chamadas a um prazer inalcançável.

No romance, a sereia metaforiza a ambivalência cultural de Esther presa ao judaísmo tradicional e à sua vivência no âmbito de uma cultura de maioria cristã, a sua condição ambígua de emigrante e imigrante, de prostituta e mãe, mas, principalmente, sua natureza feminina, espécie de arquivo que guarda o segredo daquilo que os homens desejam nas mulheres, e que não podem alcançar para continuar desejando-as.

É também possível associar a linguagem à forma anfíbia da sereia, se se pensa em seu movimento sinuoso que perfaz o caminho do dizer ao dito. Nunca há uma correspondência absoluta entre ambos, entre a incompletude do dizer e a suposta completude do dito. É só na arte que esse paralelismo se enquadra de outra maneira, por armar a palavra de uma força expressiva que a faz evocar no dito os sentidos calados. Embora Marcos busque a sereia nas águas, é na linguagem que ele a encontrará.

Mas ela está também, em sua contraface rebaixada, no bordel, entre outras prostitutas de variadas procedências, incluindo uma japonesa e uma sueca. 
Sou francesa, dizia aos clientes mais curiosos. Esther Marc era agora o seu nome, não mais Esther Markowitz. Um advogado the providenciara novos papéis. Vestia-se bem: longos vestidos escuros, jóias. Um cabeleireiro vinha penteála todos os dias. Entre seus clientes estavam figuras de projeção: o deputado Deoclécio, filho do fazendeiro Mathias, vinha todas as sextas-feiras. Visitantes de outros Estados eram encaminhados à Casa; Esther recebia-os pessoalmente, oferecialhes bebidas, auxiliava-os na escolha das mulheres. [...] Administrava a Casa com mão de ferro. ${ }^{33}$

Prostituta ou dona de bordel, a clientela de Esther é a mesma que freqüentava o "Paradis Retrouvé", de Mme. Pommery: políticos, coronéis, jornalistas, profissionais liberais, mas enquanto esta não se deixa seduzir em momento algum, Esther é mais pungente, sente prazer com o sexo e, algumas vezes, se deixa mover pela paixão. Talvez por isso a primeira seja mais bem-sucedida em seus projetos. Ambas, porém, seduzem, mas não se realizam amorosamente.

Como excluir um filho homem da sedução que Esther exerce sobre o universo masculino, de modo a não desobedecer a lei que interdita o incesto? Ele terá de lançar mão da mediação da pesquisa e, escudado por ela, fará uma viagem microscópica para investigar nas águas podres de um córrego da Vila Santa Luzia a origem mitológica da vida, de sua vida. O que ele busca na favela que se nutre do riacho e ao mesmo tempo alimenta sua contaminação ("Por que a água aqui é limpa e mais adiante não é?"34) é o fundamento mítico de sua origem: sua mãe, a sereia devoradora de larvas e micróbios. E, para evitar ser devorado por ela, pagará o preço de seu sedentarismo. Ele fará as escolhas de sua vida de modo a suprimir dela o seu caráter inquietante; ao clarificar, elucidar, distinguir e separar o que não deve ser confundido, ele procura emprestar um sentido às coisas, resguardando-se da aventura de viver o semsentido do desejo. Por isso, o romance é narrado por ele, mas abre-se também a outros enfoques que iluminam os seus pontos de cegueira. 
Como Hilário Tácito, Moacyr Scliar utiliza-se de fonte histórica para compor seu texto. De fato, a organização mafiosa Zwi Migdal existiu ${ }^{35}$ foi fundada na Polônia e mantinha sua sede central em Buenos Aires, desde 1904, quando apareceu pública e legalmente como Sociedade Israelita de Socorros Mútuos Varsóvia. Responsável pela importação de muitas prostitutas para a Argentina e o Brasil, a sociedade atuava em várias cidades brasileiras, embora não de maneira tão imperiosa quanto na Argentina, onde o desenvolvimento da prostituição garantia altas taxas de lucro.

Mesmo que o número de moças traficadas tenha sido proporcionalmente pequeno, e, no Brasil, tudo indica que as brasileiras superavam o número de prostitutas estrangeiras, o fenômeno teve repercussões amplas, a ponto de se associar o termo "polaca" a "prostituta", principalmente no Rio de Janeiro e em São Paulo.

Se, por um lado, registra-se uma exploração anti-semita da presença de prostitutas judias no Brasil, ${ }^{36}$ argumento fartamente mobilizado durante o Estado Novo, por outro, o apelo do exotismo e da valorização da estrangeira enquanto figura da modernidade, em oposição à negra escrava do passado colonial, dará relevo às polacas. Mário Praz ${ }^{37}$ observa que, enquanto Merimée, em meados do século XIX, criava Carmen, mulher fatal proveniente da Espanha, no final desse mesmo século o tipo da mulher fatal estava na Rússia, onde o erótico e o exótico passam a caminhar juntos. Como a mulher judia combinava o exótico ao místico no imaginário social, pois além de vir de longe - o que já era a promessa de um contacto diferente e excitante - ela professava num país de maioria cristã um credo religioso estranho e minoritário, a combinação devia funcionar de modo considerável.

Embora Moacyr Scliar tenha se cercado de informações históricas, elas são ficcionalizadas. No intervalo entre ficção e história, entre duas culturas, também Scliar, como sua personagem, se faz representar simbolicamente pela sereia, não só porque ela junta suas metades diversas, mas também porque, como escritor, ele une-se a ela em seu canto. 


\section{Sexo em japonês}

"O mistério da prostituta japonesa" é um conto de Valêncio Xavier, ${ }^{38}$ inserido em O Mez da Grippe e outros livros, ${ }^{39}$ de 1998.

A ação se passa em São Paulo, bairro da Liberdade, onde se concentra uma comunidade japonesa já em terceira geração, ${ }^{40}$ tomando como referência os imigrantes que aqui aportaram no início do século XX. O bairro, embora tenha perdido muitas de suas características originais, ainda guarda rastros da comunidade que o constituiu, perceptíveis na comida típica, nos cinemas (ainda que mais ativos na década de 70, quando se projetavam filmes exclusivamente japoneses), num tipo de ornato visível na decoração de interiores e de algumas ruas, na cerâmica e na louça utilitária de bares e restaurantes, nas academias onde se praticam lutas trazidas do Japão. É nesse bairro, num hotelzinho barato, que se dará o encontro entre a prostituta japonesa e seu cliente brasileiro.

Integram o conto: o desenho de uma mão com versos do poeta surrealista Robert Desnos nela inscritos, uma planta do quarto onde a prostituta e o narrador protagonista têm o encontro, e escritos caligráficos japoneses. É curiosa a perspectiva com que a planta do quarto é construída, pois ela representa o espaço situando aquele que vê (o leitor) numa posição externa| e verticalmente acima dele, apesar de o relato em primeira pessoa dirigir-se a um "tu", o leitor, indicando proximidade. O hotelzinho de rendez-vous é labiríntico, precário e pobre, não dispõe de água quente, os móveis atravancados se comprimem num espaço exíguo, em descompasso com as dimensões do ambiente que os contém. Os quartos são cubículos que impedem uma disposição planejada tanto dos móveis, que têm de estar onde cabem, como das pessoas, que têm de se dirigir ao pequeno banheiro ou ficar sobre a cama, porque não há área de circulação. O olhar à espreita do leitor acompanha a japonesinha caminhando no escuro com passos ligeiros adiante de seu parceiro, por caminhos obscuros, passando por portas fechadas, num longo corredor es- 
treito, cortado por escadarias e por outros corredores, o que leva a supor sua familiaridade com o mapa desse espaço revisitado.

O cenário do quarto é o de um hotel de encontros, onde não falta a luz vermelha ambiente, nem a colcha de tecido brilhante, também vermelha, cheirando a mofo devido à falta de ventilação. No quarto, o homem e a mulher iniciam um diálogo e, aí, surge a surpresa: a mulher fala em japonês, e o texto é grafado em caracteres japoneses -, o que exclui o interlocutor e o leitor do entendimento de sua fala. Assim, o leitor é lançado outra vez ao escuro do corredor, mas sozinho, pois o homem não se espanta, não se surpreende diante da mulher que se dirige a ele em idioma estrangeiro. Há um certo automatismo nas falas casuais que funcionam como pretexto para a frágil sustentação do diálogo. O automatismo estende-se aos gestos, à procura do comutador de luz, ao olhar neutro do homem que vê a mulher se lavando no bidê, à mulher imóvel como uma fotografia estendida ao seu lado na cama, ao movimento da mão que afaga e apalpa o corpo. Em seguida, o sexo mudo e imediato, os clichês ditos após o coito, o dinheiro pago conforme o combinado, o caminho de volta pelos corredores que os leva à portaria, o pagamento da comissão que o chinês da portaria faz à prostituta por ter escolhido aquele hotel e não outro.

O que salta à vista é o aprisionamento dos protagonistas desse episódio, cada um atado à camisa-de-força de uma mitologia herdada de que se auto-alimentam, mas que os transforma em agentes de sua reprodução. Por isso, não importa o que a japonesa diz, nem importa se seu idioma é desconhecido do homem e vice-versa, pois, em verdade, cada uma fala para si. Também a aura de mistério que envolve a japonesa é feita do clichê da mulher oriental. Qual sua idade?

Nem moşa, nem velha. Não sei dizerer. Difícil dizer a idade das mulberes orientais. [...] Não sei o que ela sentiu. Permaneceu, permanece silenciosa e não sei para onde olha. [...] Mas teria mesmo gozado?41 
Os corpos convertidos em mecanismos são frases dobradas sobre si mesmas cujo sentido se evapora. Movendo-se no interior de um erotismo solitário, confinados a uma espécie de auto-sexualidade, homem e mulher se perdem neles mesmos, cerco autofágico de esterilidade e morte. O protagonista narrador reitera a pergunta, "teria ela gozado?". A inquietação construída sobre o alcance de sua masculinidade permanece sem resposta, mas entra no rol de questões guardadas no arquivo de fábulas e clichês, onde o homem precisa acreditar que provocou o orgasmo na mulher, enquanto ela finge tê-lo atingido. Mas, ao mesmo tempo, essa pergunta incide sobre a possibilidade de ruptura do cerco narcísico, através do sexo. Mas, alheados, cada um segue seu caminho, neutralizados pelas máscaras que estampam as marcas da vida contemporânea.

O conto se fecha com a manifestação de que o narradorpersonagem se deixa fisgar pelo mistério da prostituta japonesa:

Muitas vezes dormi com outras prostitutas no mesmo quarto do botelizinho barato, mas sei que nunca mais verei a prostituta japonesa, nem saberei se ela sentiu prazer comigo naquela noite escura. Às vezues penso que sim; às vezes, penso que não. Nunca encontrarei uma resposta que me satisfaça. ${ }^{42}$

Fazendo o conto dialogar com o desenho inscrito no alto da página, onde uma mão vazia e aberta é atravessada por um poema disposto em versos grafados sobre quatro dedos,
tanto sonbei contigo
tanto amei tanto fale $i$
tanto amei tua sombra
que nada mais me resta de ti,

tem-se a indicação de um rebaixamento, de uma queda irônica do amor e do desejo intensos que se exaurem no ato mesmo de amar, para uma 
espécie de imitação vazia do sexo, em que a mão estendida, que poderia ser lida como desejosa de contacto, conota também sua impossibilidade.

A sentença do vazio é marcante para o homem, porque a prostituta japonesa integra, com certeza, a mitologia da mulher diferente, portadora de mistérios ancestrais, desenhando no imaginário masculino a figuração diferencial do outro, que estimula o desejo a desenfrear a rédea da fruição para atingir um gozo estrangeiro. O amor, o desejo, a mulher, são símbolos de uma aspiração maior. Mas é na clausura do quarto de hotel que o homem tem de se haver com o rebaixamento e com a intangibilidade da fantasia. Preso a um movimento pendular que oscila de alto a baixo, cujo desenho não consegue desfazer nem imprimir-lhe nova direção, o protagonista insiste em continuar na companhia da prostituta:

Quer tomar alguma coisa? V amos num barzinho aqui por perto?

Antes da resposta, sai sozinha do hotel outra prostituta. Não é japone-

sa. Tem mais jeito de turca, síria, qualquer coisa assim. Meio velhusca, formas roliças, peitos, barrigas e nádegas querendo romper o vestido justo. [...] As duas se conbecem, devem ser muito amigas. Riem, se tocam e falam rapidamente, risos, a voz de uma encobrindo a da outra. [...]

- Vamos? ${ }^{43}$

Já se afastavam as duas amigas, quando o protagonista lhe estende a mão aberta, que permanece suspensa (é nela que se inscreve o poema do surrealista Robert Desnos). Mas a mulher recusa o convite. O dinheiro é, talvez, o dique que barra a intimidade indesejável com o homem, circunscrevendo a relação possível entre eles. Caberá ao homem ruminar a dúvida sobre o mistério da mulher. Quem é ela? O leitor não sabe, porque está acima e fora da cena, mas não sabe também estando dentro, pois acompanha-a refratada pelo olhar do narrador-protagonista, que deixa no final, a descoberto, o ponto-de-fuga que assinala o centro de seu desamparo. 


\section{Cruzando caminhos}

Da arrivista e premeditada Mme. Pommery, personagem de uma Belle Époque tropical regada a champanhe, cuja atuação representou um dos móveis das transformações modernizantes da cidade de São Paulo, à silenciosa prostituta japonesa sem nome, atuando num hotel barato de bairro da mesma cidade, mero ponto de passagem e não mais espaço de sociabilidade, muita água correu. Embora a ação do conto não seja datada, tudo indica tratar-se das últimas décadas do século XX, quando a imigração externa maciça estancou seu fluxo e mudou de direção. São os brasileiros filhos e netos de japoneses que voltam ao Japão para escapar do desemprego e conseguir ganhar a vida. Lá, eles são os imigrantes que deverão apagar os traços do país de origem, reduzindo seu corpo a braço de trabalho. Quanto às prostitutas estrangeiras, em relação a elas ainda restam os ecos de um imaginário ativo, embora sob o impacto de novas formas ainda difíceis de discernir.

As respostas à relação antagônica que opõe desejo, prazer a trabalho, lei, desenham diferentes caminhos. Nos três textos apresentados, o corpo feminino, "pernas vagabundas", é mercadoria que aglutina trabalho, lucro e prazer, não se confundindo nunca o feminino com o sexo anatômico, aliando-se, ao contrário, à fábula da qual não se sai, a história individual e coletiva, a cultura, e o modo como o sujeito negocia com esses esquemas, a eles se adapta e os reproduz, ou então os contorna, supera, ultrapassa, atravessa, para alcançar ou jamais chegar a alcançar algum ponto carente de medo e remorso, onde algo simplesmente se move, como as aquarelas sobre papel de Cézanne, que têm um poder de irradiação da luz a partir do vazio.

O processo de fragmentação a que se submetem as representações artísticas está ligado ao desenvolvimento técnico que data de fins do século XIX. O Impressionismo é o primeiro exemplo de arte urbana por excelência, não porque descobre a cidade como paisagem, mas principalmente porque vê o mundo com olhos urbanos. A versatilidade, o 
ritmo nervoso, as impressões súbitas, agudas, efêmeras da vida urbana, a transformação da duração em momento, do perfeito em inacabado. Da metáfora em metonímia. Parte. Mas parte que conserva o elo de contigüidade espacial e temporal com a seqüência mais longa na qual se insere. Parte "contaminada" porque só se completa na extensão dos elementos de que se constitui para a realidade que lhe é contígua. Fragmento que surge como resultado de um processo de desarticulação do mundo mas se completa positivamente pelo elogio dessa desarticulação. A parte remete ao todo. É o dinamismo, a tecnologia que está por trás desse procedimento: a ideologia do progresso.

Circula pelo romance Mme. Pommery, particularmente no bordel que funciona como as entranhas de uma cidade progressista, uma euforia regada a bebidas, estimulada pela descoberta de novos modos de vida e de lazer. É o tom de deboche e ironia do autor/narrador que impede que essa afirmação seja absoluta, mas o livro, ao mostrar o progresso, aponta para um horizonte de expectativas, em medida nacional, onde o arrivismo e o "favor" têm lugar de destaque. Já em (O Ciclo das Águas), porque escrito nos anos 70, a empatia com o progresso técnico se desfaz. Embora a ação do romance se inscreva nos anos $20 / 30$, o autor se insere num contexto não mais de expectativas, mas de realidade. Por isso, o mesmo parcelamento da realidade é oferecido com as tintas do desencanto. E o bordel, aí, refrata o moto placentário que autentica a passagem do tempo, a vida e a morte, o rebaixamento do mito, e uma vontade da forma voltada para o desejo de fixar o corpo da mãe, entendê-lo, explicá-lo, e neutralizá-lo. No conto "Mistérios de uma prostituta japonesa", o bordel transforma-se num hotel de encontros isolado, espécie de "ato mudo" em meio à cidade penetrada pela palavra, um lugar equivalente a tantos outros, lugar de passagem, que se multiplica em escadarias e corredores labirínticos e que, ao contrário da estrutura de encaixe (mise en abîme) de (O Ciclo das Águas), onde o trânsito em círculos das personagens reproduz a circularidade da forma do romance, e de Mme. Pommery, cujo bordel se organiza como o microcosmo da cidade, arma-se através de uma es- 
trutura que faz por eliminar a profundidade, algo como uma mise en plateau, onde o abismo é a superfície uniforme e repetitiva do dia-a-dia, que desmancha qualquer aparência de totalidade.

Tudo somado, nos três textos, nem "pernas" nem "braços" apresentam a possibilidade de ganhar corpo, e é em torno dessa ausência de totalidade que as narrativas se expandem.

\section{Notas}

1 Antes de 1920, o governo federal, que representava os grandes fazendeiros, apoiava a "europeização" do Brasil, o que significava mais que simplesmente substituir o trabalho escravo pelo assalariado; significava o branqueamento literal do que era considerado uma cultura degenerada, negra e mestiça. Após os anos 30, o consenso existente entre os agentes brasileiros do poder em relação à política imigratória cai por terra à medida que o governo federal inicia sua tentativa de centralizar o poder ao invocar novas ideologias que apoiassem o autoritarismo político federal. Isso levou a uma divisão entre aqueles que haviam detido o poder anteriormente e o novo regime. As elites tradicionais, geralmente compostas por grandes fazendeiros, continuavam a favorecer a mãode-obra barata acima de qualquer coisa, mostrando-se até mesmo ocasionalmente dispostas a apoiar a entrada de grupos culturalmente indesejáveis, como os japoneses. Contudo, a posição favorável à "mão-de-obra barata" era crescentemente combatida por uma coalizão de grupos que buscavam restringir ao máximo a imigração. Os militares, fortemente imbuídos de idéias racistas comuns entre autoritários europeus e temerosos de que os estrangeiros trouxessem o comunismo para o país, argumentavam em favor de uma suspensão quase total da imigração. Políticos também utilizavam uma retórica xenofóbica e lutavam por uma legislação imigratória restritiva. Os sentimentos da classe média eram reforçados por grupos nativistas, especialmente após o crash econômico de 1929. Tais organizações buscavam a volta a uma política de imigração que colocasse a cultura cristã européia acima de todas as outras. Cf., a propósito, Jeffrey Lesser, O Brasil e a Questão Judaica; Imigração, diplomacia e preconceito. Rio de Janeiro: Imago, 1995, p. 33 e segs. 
2 Abdelmalek Sayad, A Imigração ou os Paradoxos da Alteridade (trad. Cristina Murachco). São Paulo: Edusp, 1998. O autor, nascido na Argélia, mas radicado na França, estuda os imigrantes argelinos que vivem em Paris, Nanterre ou Saint-Denis, e também aqueles que retornaram às suas aldeias de origem na Cabília, os favelados de Argel, de Constantina etc. O sociólogo trabalha com um dado que escapava a todos os observadores que abordavam a "imigração", restringindo-se ao ponto de vista da sociedade receptora, o que lança luz ao problema dos "imigrantes" apenas quando os imigrantes "constituem um problema"; os analistas omitiam as questões sobre as causas e os motivos que poderiam ter determinado as partidas e sobre a diversidade das condições de origem e das trajetórias. Abdelmalek rompe com esse etnocentrismo inconsciente e devolve aos imigrantes a sua origem e todas as particularidades a ela associadas e que explicam muitas das diferenças observadas nos destinos posteriores.

3 Cf. Jeffrey Lesser, O Brasil e a Questão Judaica. (trad. Marisa Sanematsu), op. cit.; Maria Luiza Tucci-Carneiro, O Anti-Semitismo na Era Vargas (1930-1945). São Paulo: Brasiliense, 1988; Henrique Rattner, Tradição e Mudança (A Comunidade Judaica em São Paulo). São Paulo: Ática, 1977; Boris Fausto (org.) Fažer a América. São Paulo: Edusp, 2000.

4 A prostituição estrangeira existe no Rio de Janeiro desde o início do século XIX. Durante a primeira metade do século passado, as prostitutas eram portuguesas tanto do continente, como dos Açores e da Madeira, ou escravas de ganho induzidas a esse trabalho por seus senhores. A partir de meados do século, o panorama modifica-se, com a chegada de mulheres vindas da Europa e que se instalam tanto no Rio de Janeiro, em Santos, em São Paulo, como nas principais cidades-porto do país. Do diversificado leque de nacionalidades destinadas ao mercado da prostituição, francesas e polacas são as que se tornam sinônimo de prazer. Tal status circunscreve-se ao fenômeno da belle époque vivido pelas principais cidades brasileiras - Rio de Janeiro e São Paulo - e do continente como um todo. Assim, a influência francesa dita modas e idéias, arquitetura e comportamento, valores e atitudes para as elites políticas e intelectuais, impondo o fetichismo da mercadoria européia que vai da roupas às mulheres. Cf. Beatriz Kushnir, Baile de Máscaras. Rio de Janeiro: Imago, 1996; Margareth Rago, Os Prazeres da Noite. Rio de Janeiro: Paz e Terra, 1991; Míriam Moreira Leite, A Condição Feminina no Rio de Janeiro (Século XIX). São Paulo: Hucitec/Edusp/INL, Fundação Nacional Pró-Memória, 1984; 
Martha de Abreu Esteves, Meninas Perdidas (Os populares e o cotidiano do amor no Rio de Janeiro da Belle Époque). Rio de Janneiro: Paz e Terra, 1989; Luis Carlos Soares, Rameiras, Ilhoas, Polacas... São Paulo: Ática, 1992; Néstor Perlongher, O Negócio do Michê. São Paulo: Brasiliense, 1987.

5 Mário de Andrade, Macunaíma: o herói sem nenbum caráter. Ed. crítica, Telê Ancona Lopes (coord.), $2^{\text {a }}$ ed. Madrid/Paris/México/Buenos Aires/São Paulo/Rio de Janeiro/Lima: ALLCA XX, 1996.

6 Cf. o ensaio de Maria Augusta Fonseca, “A carta pras Icamiabas", in Macunaima, ed. crítica, op. cit., pp. 329-345.

7 Machado de Assis, Memórias Póstumas de Brás Cubas, in Machado de Assis, Obra Completa, Vol. 1, Rio de Janeiro: Aguilar, 1962.

8 Adolfo Caminha, O Bom Crioulo. Rio de Janeiro: Edições de Ouro, 1964.

9 Mário de Andrade, Amar, Verbo Intransitivo. $3^{a}$ ed. São Paulo: Martins Fontes, 1962.

10 A observação é de Francisco de Oliveira em curso de pós-graduação no programa de Literatura Brasileira, USP, 2000.

11 Hilário Tácito, Madamme Pommery. São Paulo: Ática, 1998.

12 Cf. entrevista de Paula Ester Janovitch à esposa do autor - Maria de Toledo Malta Ferraz. Ver dissertação de mestrado O Menir de Pommery: a cidade de São Paulo na literatura (1890-1920), PUCSP, inédito. Essa dissertação constrói-se sobre a análise de Madamme Pommery, de Hilário Tácito. Através da análise da protagonista, a autora monta a história da cidade de São Paulo, indo do referente à ficção, confundindo-se os limites entre ambos, e, desse entrelaçamento, extrai interessantes conseqüências.

13 Cf. a esclarecedora e aguda apresentação ao livro feita por Eliane Robert Moraes.

14 Cf. Michel Maffesoli, A Sombra de Dionísio. Rio de Janeiro: Graal, 1985. A reflexão desse sociólogo escapa da apreensão insistentemente normativa que caracteriza muitos trabalhos sobre o tema, privilegiando a função agregativa da prostituição, considerandoa lugar onde se refazem as solidariedades subterrâneas fundamentais.

15 "Pernas estangeiras, pernas de cantoras, pernas de bailarinas, são por natureza pernas vagabundas", p. 55.

16 Madamme Pommery, op. cit., p. 31.

17 Idem, p. 31. 
18 Ibidem, p. 43.

19 Ibidem, p. 55.

20 Ibidem, p. 122.

21 Cf., a propósito, o ensaio de Carlos Eduardo Schmidt Capela, "O Industrial e a Prostituta no País dos Coronéis" (xerografado), onde o autor compara Madamme Pommery, de H. Tácito, a O Estrangeiro, de Plínio Salgado. Devo a esse ensaio algumas posições de meu trabalho.

22 Madamme Pommery, op. cit., p. 131.

23 Idem, p. 123.

24 Em Os Prazeres da Noite, op. cit., Margareth Rago estuda o romance de Hilário Tácito, no subcapítulo “A Máquina de Eva”. Ela enfatiza a função “civilizadora” da prostituição e o instinto empresarial da protagonista.

25 Madamme Pommery, op. cit., pp. 74-75.

26 Moacyr Scliar, (O Ciclo das Aguas). Porto Alegre: Globo, 1977.

27 Aquele que pratica o ritual da circuncisão.

28 Esses são os pontos de vista que prevalecem, mas há outros.

29 (O Ciclo das Águas), op. cit., p. 17.

30 Ritual de passagem, inicia o menino, aos treze anos, na maioridade.

31 Ritual de passagem, inicia a menina, aos doze anos, na maioridade.

32 (O Ciclo das Águas), op. cit., p. 84.

33 Idem, pp. 78-79.

34 Ibidem, p. 53.

35 Cf. Margareth Rago, op. cit., “O Tráfico de Escravas Brancas”. Nesse capítulo, a autora trata do tráfico de prostitutas estrangeiras para o Brasil e para o Continente de modo mais amplo, dedicando uma parte para a Organização Zwi Migdal. Ver. pp. 291309. Cf., ainda, o livro de Beatriz Kushnir, O Baile de Máscaras, op. cit., dedicado a estudar o tráfico de "polacas" para o Brasil e a tentativa dessas mulheres de sair do lugar de exclusão, refazendo no dia-a-dia a referência que lhes dava sentido e direção: sua condição religiosa e sua herança cultural.

36 Cf. Jeffrey Lesser, Pawns of the Powerful. Jewish Immigration to Brazil, 1904-1945. New York University, 1989, mimeo. 
37 Mário Praz, "A Bela Dama Sem Misericórdia”, em A Carne, a Morte e o Diabo na Literatura Romântica (trad. Philadelpho Menezes). Campinas: Ed. Unicamp, 1996.

38 Valêncio Xavier nasceu em São Paulo, em 1933, e vive em Curitiba. Como ficcionista publicou, além de $O$ mez da grippe e outros livros, Minha mãe morrendo e o menino mentido (São Paulo: Companhia das Letras, 2001). Sua produção estende-se também para o cinema e para o vídeo.

39 Valêncio Xavier, O mez da grippe e outros livros. São Paulo: Companhia das Letras, 1998. Todos os textos incluídos contêm ilustrações ou outros recursos gráficos, pensados pelo autor como elementos integrantes da narrativa. A primeira versão desse conto foi publicada no $\mathrm{n}^{\mathrm{o}} 117$ da revista Quem, de Curitiba, em agosto de 1984.

40 O japonês-brasileiro, ou seja, o descendente de japonês, é atualmente denominado nikekei, não importa a que geração pertença. Essa denominação está sendo utilizada desde a Convenção Panamericana Nikkei, ocorrida em 1985, em São Paulo, que adotou essa terminologia para todos os descendentes de japoneses nas Américas, substituindo a terminologia anterior, nisei, para os descendentes dos imigrantes, e sansei, para os descendentes de terceira geração. Cf. Célia Sakurai, Romanceiro da Imigração Japonesa. São Paulo: Fapesp/Idesp/Ed.Sumaré, 1993 (série Imigração, vol. 4).

41 Valêncio Xavier, O mez da grippe..., op. cit., pp. 188-189.

42 Idem, p. 191.

43 Ibidem, p. 190. 